\title{
Regional variation in homicide rates of infants and children
}

\author{
David Lester
}

\begin{abstract}
Goal-This study examines regional correlates of homicide rates for infants and children for the states of America.
\end{abstract}

Sample-The sample consists of all homicide victims in the 48 continental, contiguous states of America in both 1980 and 1990 from the ages of $0-14$.

Methods-The homicide rates of infants aged $0-1$ and children aged $1-4$ and 5-14 were correlated with social indicators for the American states in 1980 and 1990.

Results-In 1980, children aged 1-14 had higher homicide rates in the more generally violent, urban, and socially disorganized states. However, no correlates for the homicide rate of infants were identified, suggesting that different theories may be required to explain their deaths. The analyses were repeated using data for 1990 , at which time crime rates and fewer medical facilities were more weakly associated with the homicide rate of infants.

Conclusions-The results suggest that different sociological theories may be required to account for the regional variation in the homicide rates of infants from those used for explaining the variation in the rates of children.

(Injury Prevention 1996; 2: 121-123)

Keywords: infanticide, homicide, regional variation.

Infanticide is of interest to psychologists and psychiatrists who have studied the adult murderers of these victims, and to sociologists and anthropologists who have studied the characteristics of those societies where infanticide is common.

Resnick found that the most dangerous period is the first six months of life, ${ }^{1}$ after which the risk of being killed decreases until puberty. The most common motives for infanticide were altruistic (to relieve real or imagined suffering in the child), revenge on a spouse, because the child was unwanted, or unintentional, as a result of child abuse. In England, D'Orban found a similar typology of motives. ${ }^{2}$

Minturn and Stashak reported that $53 \%$ of non-literate, primitive societies practiced infanticide, usually of the neonate and, typically, by the mother. ${ }^{3}$ The most common reasons were that the child was illegitimate, deformed, or one of twins or triplets. Minturn and Stashak concluded that infanticide in these societies was a form of birth control.
In a study of industrialized nations, Lester found that the homicide rate for children was not associated with the total homicide rate (that is, including adults) of the countries, but rather with the suicide rate. ${ }^{4} \mathrm{He}$ explained this association by noting that the murder of young children is often accompanied by the suicide of the parent. Christoffel et al, have confirmed this association. ${ }^{5}$

The present study of the regional association of the murder of children in the United States explores two issues. First, the associations of the homicide rate of infants and of children with both the total homicide and total suicide rates (that is, for the whole population) were examined to see whether they were positively correlated.

The second issue was to test five possible explanations for the homicide rates of children:

(1) In a factor-analytic study, Lester found that indices of social disorganization were correlated with one another over the states of America and were associated with homicide rates. ${ }^{6}$ The present study examined whether these indices of social disorganization were associated with the homicide rates of infants and children.

(2) The homicide rates of infants and children might simply be a reflection of a high level of general violence in a community. The present study examined the associations between the homicide rates for infants and children and the general level of violence in the region, both internal (suicide rates) and external (violent crime rates, which includes murder, manslaughter, sexual assault, assault, aggravated assault, and armed robbery).

(3) Doerner and Speir have argued that homicide rates might be higher in some communities simply because there are inferior medical services in those communities, ${ }^{7}$ with the result that people die after assaults more often in those communities than in communities with better medical facilities. The present study used the same indicators of the adequacy of medical facilities in a community as those used by Doerner and Speir to see whether they predicted the homicide rates.

(4) There is good evidence that economic hardship in general, and high rates of unemployment in particular, increases the level of violence and psychiatric disorder in communities. ${ }^{8}$ This study examined the influence of the economy on the homicide rates of infants and children.

(5) As studies of individuals who murder their children suggest that unwanted births and revenge by partners over infidelity may play a part in infanticide, ${ }^{1}$ the association between the percentage of illegitimate births and the homicide rates was examined. 


\section{Methods}

The data used were for the 48 contiguous continental states of the US in 1980 and 1990. Three homicide rates based on mortality statistics ${ }^{9}$ were examined: for children aged $0-1$, $1-4$, and 5-14 years.

Social indicators were taken from a data set previously established and described by Lester. ${ }^{6}$ Measures of social disorganization were the divorce rate, the interstate migration rate, alcohol consumption, and church attendance. Measures of the general level of community violence were the suicide rate, the total crime rate, the homicide rate, and the violent crime rate. Indices of the adequacy of medical facilities were hospital expenditures per capita beds per capita, physicians per capita, and infant mortality rates. Indices of the economy were the percentage of people living in poverty, the median family income, the percentage of people living in urban areas, and the unemployment rate. The indicator for unwanted children was the percentage of illegitimate births.

An effort was made to replicate the study using 1990 data. However, several variables were not available in 1990 (church attendance, alcohol consumption, and hospital expenditures per capita).

Table 1 Correlations between social indicators and homicide rates for three age groups, 1980 , for 48 contiguous states of the USA

\begin{tabular}{|c|c|c|c|}
\hline & \multicolumn{3}{|c|}{ Homicide rates } \\
\hline & $0-1$ & $1-4$ & $5-14$ \\
\hline Divorce rate & -0.09 & $0 \cdot 31^{\star}$ & $0.32^{\star}$ \\
\hline Migration rate & -0.05 & $0 \cdot 29 \star$ & $0 \cdot 27^{\star}$ \\
\hline Church attendance & 0.08 & $-0 \cdot 22$ & $-0 \cdot 10$ \\
\hline Alcohol consumption & $-0 \cdot 11$ & $0 \cdot 17$ & $0 \cdot 30^{\star}$ \\
\hline Suicide rate & -0.01 & $0 \cdot 36^{\star}$ & $0 \cdot 26$ \\
\hline Homicide rate & 0.04 & $0 \cdot 31^{\star}$ & $0 \cdot 32^{\star}$ \\
\hline Crime rate & $0 \cdot 18$ & $0 \cdot 40^{\star \star}$ & $0 \cdot 49^{\star \star \star}$ \\
\hline Violent crime rate & 0.04 & $0.32^{\star}$ & $0 \cdot 46^{\star \star \star}$ \\
\hline Per capita expenditures for hospitals & $0 \cdot 32^{\star}$ & -0.02 & -0.05 \\
\hline Beds/capita & -0.09 & 0.05 & $0 \cdot 23$ \\
\hline Physicians/capita & 0.07 & 0.03 & $0 \cdot 13$ \\
\hline Infant mortality & $0 \cdot 10$ & 0.06 & 0.08 \\
\hline${ }_{0}$ In poverty & -0.01 & -0.07 & $-0 \cdot 12$ \\
\hline Median family income & -0.04 & $0 \cdot 15$ & $0 \cdot 26$ \\
\hline Urban population & $0 \cdot 26$ & $0 \cdot 30^{\star}$ & $0 \cdot 44^{\star}$ \\
\hline Unemployment rate & 0.05 & 0.02 & -0.05 \\
\hline${ }_{0}^{\circ}$ Illegitimate births & $0 \cdot 14$ & $0 \cdot 12$ & $0 \cdot 13$ \\
\hline
\end{tabular}

Two tailed p value: $\star<0 \cdot 05, \star \star<0 \cdot 01, \star \star \star<0 \cdot 001$.

Table 2 Correlations between social indicators and homicide rates for three age groups, 1990 , for 48 contiguous states of the USA

\begin{tabular}{|c|c|c|c|}
\hline & \multicolumn{3}{|c|}{ Homicide rates } \\
\hline & $0-1$ & $1-4$ & $5-14$ \\
\hline $\begin{array}{l}\text { Divorce rate } \\
\text { Migration rate }\end{array}$ & $\begin{array}{l}0 \cdot 15 \\
0 \cdot 15\end{array}$ & $\begin{array}{l}0 \cdot 30^{\star} \\
0 \cdot 06\end{array}$ & $\begin{array}{l}0.38^{\star} \\
0.01\end{array}$ \\
\hline $\begin{array}{l}\text { Suicide rate } \\
\text { Homicide rate } \\
\text { Crime rate } \\
\text { Violent crime rate }\end{array}$ & $\begin{array}{l}0 \cdot 21 \\
0 \cdot 24 \\
0 \cdot 38^{\star \star} \\
0 \cdot 28^{\star}\end{array}$ & $\begin{array}{l}-0 \cdot 04 \\
0 \cdot 52^{\star \star \star} \\
0 \cdot 32^{\star} \\
0 \cdot 39^{\star \star}\end{array}$ & $\begin{array}{l}0 \cdot 01 \\
0 \cdot 76^{\star \star \star} \\
0 \cdot 49^{\star \star \star} \\
0 \cdot 65^{\star \star \star}\end{array}$ \\
\hline $\begin{array}{l}\text { Beds/capita } \\
\text { Physicians/capita } \\
\text { Infant mortality }\end{array}$ & $\begin{array}{l}-0.32^{\star} \\
0.05 \\
0.11\end{array}$ & $\begin{array}{l}-0.13 \\
-0.07 \\
0.42^{\star \star}\end{array}$ & $\begin{array}{l}-0.05 \\
-0.01 \\
0.46^{\star \star}\end{array}$ \\
\hline $\begin{array}{l}\text { In poverty } \\
\text { Median family income } \\
\text { Unrban population } \\
\text { Unemployment rate }\end{array}$ & $\begin{array}{l}0 \cdot 06 \\
0 \cdot 05 \\
0 \cdot 26 \\
0 \cdot 11\end{array}$ & $\begin{array}{c}0 \cdot 30^{\star} \\
-0 \cdot 08 \\
0 \cdot 10 \\
0 \cdot 18\end{array}$ & $\begin{array}{l}0 \cdot 34^{\star} \\
-0 \cdot 01 \\
0 \cdot 35^{\star} \\
0 \cdot 30^{\star}\end{array}$ \\
\hline \% Illegitimate births & $0 \cdot 21$ & $0.53 \star \star \star$ & $0.63^{\star \star \star}$ \\
\hline
\end{tabular}

Two tailed $\mathrm{p}$ value: $\star<0.05, \star \star<0.01, \star \star \star<0.001$

\section{Results}

The Pearson correlations shown in table 1 for 1980 indicate that the measures of social disorganization were associated with homicide rates of children 1-4 and 5-14, but not of infants.

The homicide rates of children $1-4$ and 5-14 were also associated with the total homicide rate and with the total crime and violent crime rate. Thus, children older than 1 year were murdered more often in the more violent states. However, the homicide rate for infants was not associated with either suicide or homicide rates.

Nor were the homicide rates of infants and children associated with the incidence of illegitimate births or the social indicators of the economy, though children 1-4 and 5-14 were murdered more often in the more urban states. On the whole, indicators of health care were not associated with the homicide rate for children of any age, indicating that the homicide rates of infants and children is not predictable from indices of poor medical care.

Examination of the results for the 1990 data set (table 2) indicated that the homicide rate of infants was associated with the total crime rate, though less strongly than for the homicide rate of older children. The homicide rate of infants was associated with fewer hospital beds per capita, suggesting that the adequacy of health care facilities may come to play a greater part in the regional variation of the homicide rates in the future.

With such a large data set, a multivariate analysis is of interest. For 1980 and 1990 separately, factor-analyses were run (using a principal components extraction and a varimax rotation) to identify clusters of related social indicators. For both 1980 and 1990, three independent (orthogonal) factors were identified with eigenvalues greater than unity (see tables 3 and 4).

Looking at the three social indicators with the highest factor loadings on each factor, three factors are similar in both analyses: (A) income, unemployment, and physicians per capita, (B) homicide, illegitimate births, and infant mortality, and (C) suicide, divorce, and migration.

For 1980, the homicide rates of children 1-4 and 5-14 were predicted by factor score $(\mathrm{C})$ and the homicide rate of children $5-14$ also by factor score (A). For 1990, the homicide rates of children 1-4 and 5-14 were predicted by factor score (B), a result that is quite different from 1980. It is noteworthy, however, that for both 1980 and 1990, the homicide rates of infants were not associated with any of the three factor scores.

\section{Discussion}

The results of this study provide some support for the proposed explanations for the murder of children aged 1-4 and 5-14. Support is found for the hypotheses that social disorganization, crime, and violence, and urban environments are associated with the homicide rates of children.

However, the most notable finding is that the homicide rate of infants in 1980 is not 
Table 3 Factor-analysis of the data set for 1980

\begin{tabular}{|c|c|c|c|}
\hline & \multicolumn{3}{|l|}{ Factor } \\
\hline & $\bar{A}$ & $B$ & $C$ \\
\hline $\begin{array}{l}\text { Suicide rate } \\
\text { Homicide rate } \\
\text { Crime rate } \\
\text { Violent crime rate } \\
\text { Hospital beds/capita } \\
\text { Physicians/capita } \\
\text { Infant mortality } \\
\text { Divorce rate } \\
\text { Migration rate } \\
\text { Family income } \\
\% \text { In poverty } \\
\% \text { Urban population } \\
\text { Unemployment rate } \\
\% \text { Illegitimate births }\end{array}$ & $\begin{array}{c}-0.01 \\
0.03 \\
0.76 \dagger \\
0.62 \dagger \\
0.51 \dagger \\
0.78 \dagger \\
-0.01 \\
-0.02 \\
-0.02 \\
0.86 \dagger \\
-0.70 \dagger \\
0.87 \dagger \\
-0.02 \\
0.11\end{array}$ & $\begin{array}{l}-0.11 \\
0.86 \dagger \\
0.22 \\
0.65 \dagger \\
0.50 \\
0.08 \\
0.79 \dagger \\
0.02 \\
-0.31 \\
-0.26 \\
0.61 \dagger \\
0.21 \\
0.42 \\
0.89 \dagger\end{array}$ & $\begin{array}{c}0.91 \dagger \\
0.38 \\
0.51 \dagger \\
0.35 \\
-0.31 \\
-0.29 \\
-0.26 \\
0.92 \dagger \\
0.88 \dagger \\
-0.09 \\
0.04 \\
0.16 \\
-0.17 \\
-0.16\end{array}$ \\
\hline $\begin{array}{l}\text { Pearson correlations } \\
0-1 \\
1-4 \\
5-14\end{array}$ & $\begin{array}{c}\text { homicide } \\
0.09 \\
0.21 \\
0.37\end{array}$ & $\begin{array}{l} \\
0.08 \\
0 \cdot 16 \\
0.19\end{array}$ & $\begin{array}{c}-0.01 \\
0.38^{\star \star} \\
0.35^{\star}\end{array}$ \\
\hline
\end{tabular}

Two tailed $\mathrm{p}$ value: $\star<0.05, \star \star<0.01$. + Loading $>0.50$.

Table 4 Factor-analysis of the data set for 1990

\begin{tabular}{lccc}
\hline & Factor & \\
\cline { 2 - 4 } & \multicolumn{4}{l}{$B$} & \multicolumn{1}{l}{$C$} \\
\hline Suicide rate & -0.15 & -0.10 & $0.90 \dagger$ \\
Homicide rate & 0.17 & $0.91 \dagger$ & 0.08 \\
Crime rate & $0.68 \dagger$ & 0.47 & 0.36 \\
Violent crime rate & $0.60 \dagger$ & $0.71 \dagger$ & 0.01 \\
Hospital beds/capita & $-0.60 \dagger$ & 0.04 & -0.47 \\
Physicians/capita & $0.76 \dagger$ & -0.08 & -0.47 \\
Infant mortality & -0.19 & $0.80 \dagger$ & -0.07 \\
Divorce rate & -0.15 & 0.23 & $0.88 \dagger$ \\
Migration rate & 0.23 & -0.16 & $0.84 \dagger$ \\
Family income & $0.85 \dagger$ & -0.28 & -0.26 \\
\% In poverty & $-0.66 \dagger$ & $0.63 \dagger$ & 0.14 \\
\% Urban population & $0.68 \dagger$ & 0.47 & 0.36 \\
Unemployment rate & -0.14 & $0.58 \dagger$ & 0.02 \\
\% Illegitimate births & 0.09 & $0.83 \dagger$ & -0.09 \\
& & & \\
Pearson correlations with homicide rate & & \\
0-1 & 0.23 & 0.23 & 0.25 \\
1-4 & 0.06 & $0.51^{\star}$ & 0.15 \\
5-14 & 0.17 & $0.65^{\star}$ & 0.20 \\
\hline
\end{tabular}

Two tailed $\mathrm{p}$ value: $\star<0.001$. $\nmid$ Loading $>0.50$.

associated with any of the social indicators selected except hospital expenditures per capita. None of the hypotheses examined was able to predict the homicide rate of infants. In particular, unlike studies comparing nations, this study of states in America found no association between the homicide rates of infants and the suicide rate. The results for 1990 , however, indicate that the crime rate and the availability of medical resources might now predict the homicide rate of infants.

Looking at the results from both 1980 and 1990 together, no variable was significantly associated with the rate for infants in both years. In contrast, the divorce rate, the homicide rate, the total crime rate, and the violent crime rates were significantly associated with the homicide rates of children $1-4$ and 5-14 in both years. This suggests that the general level of violence may be best predictor of the homicide rate for children, with social disorganization (as indicated by the divorce rate) playing a minor part.

The results of the multivariate analysis also indicated that no single factor score predicted the homicide rate for infants. There were significant correlates of the homicide rates for children, although these correlates were different in 1980 and 1990.

Thus, the results support those of others who have concluded that violent deaths of infants may be differently determined than that of older children. ${ }^{1}$ The results indicate that current theories (sociological, as well as psychological) may not apply to the murder of infants and that there is a need, therefore, for alternative theories to account for why infants are murdered.

1 Resnick PJ. Child murder by parents. Am f Psychiatry 1969; 126: 325-34.

2 D'Orban PT. Women who kill their children. $\mathrm{Br} f$ Psychiatry 1979; 134: 560-71.

3 Minturn L, Stashak J. Infanticide as a terminal abortion procedure. Behav Sci Res 1982; 17: 70-90.

4 Lester D. A cross-national study of suicide and homicide. Behav Sci Res 1974; 9: 307-18.

5 Christoffel K, Liu K, Stamler J. Epidemiology of fatal child abuse. F Chronic Dis 1981; 34: 57-64.

6 Lester D. Patterns of suicide and homicide in America. Commack, NY: Nova Science, 1994.

7 Doerner WG, Speir JC. Stitch and sew. Criminology 1986; 24: $319-30$.

8 Ezzy D. Unemployment and mental health. Soc Sci Med 1993; 37: 41-52.

9 National Center for Health Statistics. Vital statistics of the United States, 1980. Rockville, MD: National Center for Health Statistics, 1983. 